Goldschmidt2020 Abstract

\title{
A NEW BRGDGT-BASED \\ TEMPERATURE CALIBRATION FOR \\ LACUSTRINE ENVIRONMENTS OF THE \\ CONTINENTAL U.S. AND ITS \\ APPLICATION TO RECONSTRUCT HOLOCENE TEMPERATURES AT TWIN PONDS, VERMONT
}

\author{
IOANA C. STEFANESCU ${ }^{* 1}$, BRYAN N. SHUMAN ${ }^{1}$, LAURIE $^{2}$ \\ D. GRIGG $^{2}$ \\ ${ }^{1}$ Department of Geology and Geophysics, University of \\ Wyoming \\ ${ }^{2}$ Department of Earth and Environmental Sciences, \\ Norwich University \\ *correspondence: istefane@uwyo.edu \\ bshuman@uwyo.edu \\ grigg@ norwich.edu
}

Branched glycerol dialkyl glycerol tetraethers (brGDGTs) in lake sediments are increasingly being used as proxies for past mean annual temperatures (MAAT). The compounds have been extensively studied in tropical regions and calibrated to MAAT. However, recent studies suggest that lacustrine brGDGT distributions in temperate regions vary with lake size and environmental conditions such as seasonality and its effects on water column temperature and chemistry. Thus, the existing calibration to MAAT is not be applicable in temperate regions such as the continental United States. Here, we present a new temperature calibration based on lacustrine brGDGT distributions in 30 lakes from across the continental United States. Our sites span a wide climatic gradient with mean annual air temperatures (MAAT) ranging from 5.4 to $20.3^{\circ} \mathrm{C}$. We apply the new calibration to sediment samples from Twin Ponds, VT to reconstruct Holocene temperatures. To test our calibration, we compare our brGDGT-based temperature reconstruction against pollen inferred temperatures from the same lake. 